\title{
Tourism and COVID-19: Social and Lateral marketing to the rescue
}

\author{
AUTORA: \\ Konstantina Zerva \\ Faculty of Tourism \\ Universitat de Girona
}

\section{Introduction}

If there is something that will be globally remembered from 2020 is Coronavirus disease 2019 (COVID-19), identified in December 2019 in Wuhan, China and resulted in an ongoing pandemic. According to the World Health Organization, as of October the 4rth, there have been 34.804 .348 confirmed cases of COVID-19, including more than one million deaths all over the world (WHO, 2020). Under the knowledge that epidemics can directly affect individuals' travel behaviour (Mao et al. 2010), until an effective and safe vaccine is available at the market, the key to reducing the economic and social impact of this pandemic lies upon the influence of people's behavior.

Traditional marketing finds itself in an uncomfortable situation where inducing consumers to maintain the same behavior as before the pandemic seems inadequate. For the first time in history, the largest behavioral campaign has been developed on a global level, where words like 'hand hygiene', 'social distancing' and 'lockdown' try to guide population behavior, realizing the hard task that on many occasions the behavioral change has to be done voluntarily. Therefore, effective communication and potentially further intervention is needed so as people comply with the new conditions until safety is back. Nonetheless, in recent epidemic crisis like the outbreak of severe acute respiratory syndrome coronavirus (SARS-CoV) in 2003 in South Asia (Mao, Ding \& Lee, 2010), it became evident that extreme measures like isolation and quarantine have precipitated depression and anxiety, due to people's detachment from their loved ones (Hawryluck et al., 2004). Additionally, during the COVID-19 pandemic, the creation and dissemination and sharing of fake news, like fake cures, conspiracy stories about the origins of the virus, or fake numbers of infected people) throughout social media platforms, basically under altruistic intentions, led to misinformation and further panic (Rampersad et al. 2019; Apuke \& Omar, 2020). This indicates the delicate role of effective communication, convincing not only that a behavioral change is necessary for physical health, but also that there are alternative ways to preserve mental health. 
The good news is that there is a great deal of knowledge regarding risk communications - originated in the late 1980's - and health communications - originated even before (Menon, 2006), focusing either on emerging infectious diseases as well as long-term health risks, like smoking. On the other hand, the SARS epidemic has been a useful lesson in showing marketing examples that allowed for the tourism sector to survive and help for the quick recovery of the economic level in Southeast Asia (Tse, So \& Sin, 2006; Mao, Ding \& Lee, 2010). This paper will try to show how the communication of social and lateral marketing strategies provided tools to entice population's voluntary behavioral change during the SARS as well as COVID-19 eras.

\section{Crisis communication through social and lateral marketing during the SARS and COVID-19 era}

Communication for the same outcome on a global scale makes one thing very clear; different groups of people respond differently to available messages. This indicates that the same message must have different formats so as to reach as many people as possible, based on their values and lifestyle, and must be as convincing as possible so as the results are quickly observed. More than 20 years ago, Rothschild (1991), - based on Lindblom's (1977) three classes of social control of politico-economic systems (persuasion, exchange and authority) - has provided three primary classes of strategic tools that aim at directing targets who are prone, resistant and unable to comply with manager's goals, showing them how to behave through education, helping them to see the importance of that change using marketing, and forcing them to comply through law. These targets may or may not have motivations, opportunities and/or abilities (MOA) (Maclnnis, Moorman \& Jaworski, 1991) to adopt the new behavior, while on the other hand they are generally characterized by self-interest (which usually goes against existing behavior related to public health and social issues), looking for a rather immediate payback of the transaction under clear conditions, and are always allured by competition's existing choices or even consumer apathy (Rothschild, 1999). The combination among the three strategic tools, the target types and the MOA information processing, are seen in figure 1.

Figure 1. Applications of education, marketing and law

\begin{tabular}{|c|c|c|c|c|}
\hline \multirow{2}{*}{$\begin{array}{l}\text { Motivation } \\
\text { Opportunity }\end{array}$} & \multicolumn{2}{|l|}{ yes } & \multicolumn{2}{|c|}{ no } \\
\hline & yes & no & yes & no \\
\hline Ability & $\begin{array}{c}1 . \\
\text { Prone to behave } \\
\text { education }\end{array}$ & $\begin{array}{c}2 . \\
\text { Unable to behave } \\
\text { marketing }\end{array}$ & $\begin{array}{c}3 . \\
\text { Resistant to behave } \\
\text { law }\end{array}$ & $\begin{array}{c}4 . \\
\text { Resistant to behave } \\
\text { law }\end{array}$ \\
\hline no & $\begin{array}{c}5 . \\
\text { Unable to behave } \\
\text { Education, marketing }\end{array}$ & $\begin{array}{c}6 . \\
\text { Unable to behave } \\
\text { Education, marketing }\end{array}$ & $\begin{array}{c}7 . \\
\text { Resistant to behave } \\
\text { Education, marketing, } \\
\text { law }\end{array}$ & $\begin{array}{c}8 . \\
\text { Resistant to behave } \\
\text { Education, marketing, } \\
\text { law }\end{array}$ \\
\hline
\end{tabular}

Source: Rothschild, 1991

Within the COVID-19 pandemic, all three strategic tools of education, marketing and law have been applied so as to reach all possible targets. Some of them were motivated to behave differently, when self-interest was apparent, others were willing to change behavior but lacked opportunity because no environmental mechanisms were at hand, and others either possessed or not the skills at changing one habit or behavior for another. According to figure 1, marketing is essential in five of the eight applications of 
Rothschild's model, that is, when the target is unable to behave due to lack of opportunity or/and ability to react, and when the target is resisting to change behavior due to lack of motivation and ability.

\subsection{Social Marketing for less consumption}

Even though law enforcement applies to all targets, marketing is necessary to enhance motivation, opportunity and ability when missing, so as to promote voluntary behavioral change, meaning convince the unwilling through social marketing. More particularly, marketing is needed to reinforce the incentives that invite voluntary exchange, that is, develop choices with comparative advantage. As a neutral instrument, marketing can promote for example either recycling as a consumer behavior, or the purchase of the very product that is recycled (Peattie \& Peattie, 2008). The social marketing context offers an adequate space for the development of the MOA framework and the suggestion of proper strategies based on the stakeholder's profile (Binney, Hall \& Oppenheim, 2006). In order for the exchange to take place voluntarily and globally, social marketing has to focus significantly on the motivation variable, whether intrinsic, that is, achieving personal enjoyment, or extrinsic, meaning involving in behaviors that allow people to obtain incentives or external rewards.

In the case of the COVID-19 pandemia, from the moment it was declared as such (March $11^{\text {th }}$ ) and for the next 2-3 months, the world entered a lockdown phase, obliged by the law to stay home, while campaign messages like "Stay home, save lives" communicate in a simple way that people must limit mobility to the least possible level in order to be safe. This refers to an immediate behavioral change worldwide in terms of mobility, once again voluntarily.

Emerged in the late 1960s and 1970s from Kotler and Levy (1969) and Bagozzi (1978), social marketing deviates from its traditional format in the sense that the highest benefit is changing people's behavior (Andearsen, 2002), while having under consideration that competition refers to the behavior that must be abandoned, meaning that the competition are our own habits. For Kotler, Roberto and Lee (2002), social marketing refers to "the use of marketing principles and techniques to influence a target to voluntary accept, reject, modify or abandon a behavior for the benefit of individuals, groups, or society as a whole" (p.5). Yet, for Donovan (2011), we do not use social marketing, but rather we do social marketing. Most research done in this field refers to health promotion, such as disease control or physical activity (Dahl, 2010), or other areas like environmental protection or community mobilization (Cheng et al. 2011). In order to achieve the desired result, exchange - as in traditional marketing - is also fundamental here, where two parties are needed and value must be exchanged (Goffman, 1969), while this exchange could happen at an individual, community and structural level (Andearsen, 2002).

Connecting these three targets with the MOA framework, Andearsen (2002) presented different types of social marketing roles in order to achieve behavioural change. On an individual level, social marketing must create awareness regarding benefits and costs so as to encourage motivation, awareness regarding possible ways of reacting so as to encourage opportunity, and providing information on particular acts that must be made, so as to motivate ability. For example, placing signs of particular rules people must follow at the entrance to a beach would motivate ability, while communicating that people can actually go to the beach, as long as they follow these rules, encourages opportunity. Focusing that this is happening for the safety of your loved ones, creates motivation.

On a community level, social marketing could urge opinion leaders to motivate the masses, while urging 
businesses to provide or improve access to the various channels people need to use so as to change behavior. Once again, for ability to be encouraged, communication tools for outreach must be provided. Finally, on a structural level, social marketing can request structural rewards or penalties (like high fines for misconduct) in order to increase motivation, it can urge the use of government facilities for programs, so as to enhance opportunity, or can ask for the removal of public disincentives, for improving ability. So, in general, communication has to move within the context of explaining people why they should change behaviour, urge the system to allow for that change, show people what to do, remind them to keep on doing it, and scaring them when they tend to stop. During the pass of time, these messages must change and adapt to people's reactions, considering that time trivialises information when negative results don't come from misbehaviour (Hastings, et al. 2004) and people have an important tendency to relapse to previous behaviours, according to the stages of change model (Olsson et al. 2018).

Since COVID-19 is related to health issues, social marketing started to bloom, from the public as well as the private sector. Within the tourism industry - where mobilization is a key element for its development - an unprecedented moment arrived, where destinations and businesses such as hotels, restaurants and cultural entities like museus, asked people to stay home. This was even more interesting seen by destinations characterised by the 'overtourism' phenomenon days before the lockdown (Koh, 2020). Airlines cancelled all their flights during that period while offering back vouchers to their clients to use the ticket in the future, usually within 18 months. Brands, institutions and cultural entities declared their confidence and support towards these extreme measures of zero consumption. Therefore, in this case social marketing represents a form of de-marketing (Peattie \& Peattie, 2009).

Through the adjustment of the 4Ps of traditional marketing, social marketing created a particular recipe in order to communicate worldwide that new behaviours are necessary in order to go through the COVID-19 pandemic. One of the most challenging things to control on an individual, corporate and authoritative level is a risk that is invisible. A central premise about risk is that this begins where knowledge ends. During the lockdown, the basic message of communication that was promoted probably for the first time by the tourism sector was that everyone should stay home, therefore inducing zero consumption for the sake of people's health. This was basically done du to lackof official information regarding the nature if the virus. Promotion in social marketing basically refers to social communication (Paettie \& Peattie, 2008), which when related to health and public risk issues, it must follow some basic principles, like early communication, openness, in terms of always acknowledging problems, doubts and uncertainties, transparency in terms of presenting sources of information and process of investigation, presentation of data progress, treating people's fear seriously, encouraging and enabling self-responsibility, and making sure that all authoritative sources communicate the same message, in order to inform and not inflame the public (Menon, 2006; Hsu et al., 2017).

After the lockdown, people were facing the decision to start mobility and slowly return to some form of previous normality. Whether there was uncertainty or clear risk in people's perception, the effect of the amount and type of information sought is unquestionable (Quintal, Lee and Soutar 2010). Tourism businesses found themselves obliged to inform their potential clients on all the security measures they have taken in order to instil a sense of confidence. In contradiction to the nature of the COVID-19 as well as the SARS virus, these measures must be visible. Examples like all staff wearing protective surgical masks, the tables and chairs of bars and restaurants being disinfected after every use, or in some restaurants a 'hygiene ambassador' is greeting customers and makes sure that they use the sanitizing gel before they en- 
ter. Messages like 'business as usual,' 'welcome back', 'we are together in this', try to raise attention on the fact that the sector is prepared to offer its services under the new conditions and reduce perceived risk. More particularly, using the framework of Peattie \& Peattie (2009), instead of promoting a product, brands promoted a proposition of no consumption, like Airbnb declaring messages like "We may be apart, but we'll get through this together", or Estonia as a tourist destination tweeting "Visit Estonia... later \#stayhome". The objective is to show that everyone is on this together, that brands accept the cost of no clients, and wait for the right time to come back on the market. Moving to place, social marketing focuses on accessibility, making sure that information about what must be done is at the location where the action takes place or, in this case, where it should not place. Messages through television, social media, official webpages, that is, all information channels within one person's residence, allowed for a significant amount of information regarding what should be done.

Further on, price is substituted with the cost of involvement, which during the lockdown was not economic, but rather psychological, showing support to those that have been away from their loved ones until the end of the lockdown, and thus have protected them from possible contagion, like the MacDonald's campaign in Spain "Es hora de volver a encontrarnos" (it's time to meet again). On the other hand, the cost of non-involvement was also very present, considering misbehavior as a crime towards the weak, like Italy's harsh campaign with photos of people on the hospital bed and slogans like "Did you enjoy the bar's terrace?". The objective here is to use fear appeals, which is very commonly done in health campaigns (Hastings et al. 2004), even though its results in actual behavioural change (and not just perceived effectiveness) (MacAskill et al. 1993; Brennan \& Binney, 2010) and long-term results, that is, continuance of the indulged behaviour are rather questioned (Japerson \& Fan 2002). The basic identified reason for this failure is lack of identification with the projected profiles of people, and loss of effectiveness due to the habituation that may produce the repetition of shocking messages (Hastings et al. 2004).

At the end of the lockdown, people stopped staying home and the tourism sector was prepared to receive mainly domestic tourism (Seraphin \& Dosquet, 2020) offering at all time indications as to how clientes should behave so as to be able to safely consume. Change of habits, like washing hands, wearing masks on public spaces and respecting social distancing, turned out to be the key social rules so as consumption acts like going into a restaurant or a hotel, could be repeated. Thus, social marketing is not only used to limit consumption but also to modify it in order to assure its practice. The tourism sector anticipated that the domestic market would be the first to react and lead slowly towards economic recovery (Gössling et al. 2020), which is why the new proposition of the accommodation sector, with businesses like Airbnb saying "Go near", was clearly and directly focused upon the local market. By the location of sanitising gel dispensers at strategic parts of public spaces, like entrances, toilets etc. accessibility to a corrected habit becomes easier. The enjoyment of the choice to finally socialize with people in person requires the involvement cost of wearing a mask (and the financial cost of purchasing the mask).

\subsection{Lateral Marketing for maintaining consumption}

The COVID-19 pandemia rapidly spread all over the world uncertainty and fear regarding public health, while the global lockdown was an authoritative confirmation of an unfamiliar threat that can be controlled - for the moment - through limited mobility. This, within the tourism sector, was a major crisis for which none was prepared. This is where crisis management requires a swift and innovative solution. Albeit indications on how to control crises have a long history on an academic level (Pearson \& Mitroff, 1993; Robert \& Lajtha, 2002), on a practical level few businesses develop a crisis plan. Evolving quantitatively 
from basic social concerns, like the ones related to security, transparency, value distortion, justice, and authority, and qualitatively by developing new characteristics like higher frequency of abnormal events, crises without identifiable closure, new symbolic significance of a crisis situation, lack of recognition of warning events, and operational failure from major organizations to prevent and control them, to name a few (Robert \& Lajtha, 2002), crisis management is still lacking a creative response. Organizations, being more preoccupied and thus accustomed with preventive control in the site of crisis, turn to control expenditure and resources, lay off staff and focus on the product, provoking what is known as the threat-rigidity effect (Staw, Sanderlands \& Dutton, 1981).

Transforming a crisis into an opportunity goes back to ancient Greeks and Chinese, and requires the development of a positive polarity, using processes like the one explained by Dutton (1993). One of the most fundamental tools to be effective in a crisis response is the use of lateral thinking and consequently lateral marketing in order to pay attention to marginal techniques that are mostly adequate for the management of surprising events (Robert \& Lajtha, 2002). Raised from Edward de Bono's lateral thinking concept in 1970, related in the use of techniques in order to approach problems in alternative, indirect and even radical ways, lateral marketing is a term coined by Kolter and Trías de Bes (2003) that refers to restructuring the existing information and going from the specific to the general through the process of lateral thinking. moving away from traditional or vertical marketing which usually operated within a fixed market space changing sizes, packages, design, supplements of a product or expanding or narrowing its characteristics, lateral marketing goes beyond the logical process (Malynka \& Perevozova, 2019), as is needed in crisis situations.

The tourism industry in order to survive economically during the COVID-19 era, as in the case of the SARS epidemic in 2003-2004, followed two basic strategies; that is, reducing unnecessary expenses so as to maintain an acceptable bottom line (Tse et al., 2006; Lo et al., 2006), and turning to creative solutions, like lateral marketing, so as to stay active in the market through different roles. In the first case, for example, hotels applied pay-cuts, required their staff to take no-pay leave, rotated staff to work in different departments promoting cross-training, stopped offering some services, like buffets in their restaurants, reduced the number of operating elevators, reduced or even suspended all expenses in advertising and promoting (Lo et al., 2006), while restaurants achieved better negotiations with their suppliers of foodstuff, or their landlords to reduce rent (Tse et al. 2006). Internal and transparent communication between managers and staff regarding the exact measures taken, consulting the latter over these measures was fundamental in heightening employee's morale (Lo et al. 2006). A significant example of the result of this relationship was on some occasions, staff with no family commitments volunteered to take more no-pay leave than those with higher economic burdens.

On a creative scale, some tourism business turned to the typical change of the marketing mix, through tactics like the promotion of discounts and promotional packages for particular segments, thus encouraging consumption due to this occasional opportunity of enjoying the offered products and services at a lower price. Yet, some businesses have proven to be more risky and, through lateral thinking, they connected their brand to a different market philosophy, thus remaining active at least in the perception of the tourism market. Based on the experience of the SARS epidemic and the COVID-19 pandemic, the three basic strategies that the tourism sector has used so as to communicate its active presence whether during a lockdown or in the aftermath were through a) targeting a new market, b) creating a new product, and c) improving social image by offering the same or almost the same product for free. 
The concept of offering the same product to a different market creates uncertainty to business since their products/services were created based on a different profile of client, whose expectations are studied and relatively predictable. Directing the product to another market without investigation has its hazards, but in comparison to no consumption, less consumption sounds better. From the SARS era, hotels in Hong Kong learned that businesses could be conducted differently (Lo et al., 2006). The focus on domestic tourism is undeniable in times when mobility is considered dangerous. According to the UNWTO (2020), domestic tourism will return faster than international travel, where tourism businesses are asked to provide incentives so as to encourage people to discover their own countries. The lower prices are not just used as a typical discount technique, but rather communicated as an acquaintance opportunity for the local to meet the domestic business which until now was overpriced and directed towards the foreigner and, thus, was inaccessible for the local. A clear example of the strong incorporation of the domestic market is the creation of the "Go near" section on Airbnb, which offers accommodations for various uses of the locals, under the slogan "Settle in somewhere new. Discover stays to live, work, or just relax". During the lockdown, in Barcelona, the famous food market la Boquería, instead of counting in the tourist revenue as it did until then, redirected its product towards the elder local population by activating house delivery services through the online platform Manzaning, multiplying by 10 their sales (La Vanguardia, 18/05/20). Delivery services were also a frequently used technique for some restaurants which didn't use it before and whose clients were afraid of dining out, during the SARS epidemic (Tse et al., 2006) as well as the COVID-19 pandemic (La Vanguardia, 14/04/20).

Another example during the SARS epidemic, some hotels through the collaboration with travel agencies started working with secondary schools in organizing 'life-skill' programs for students, after knowing that many overseas educational tours were cancelled. The programs of intensive English and dining etiquette were held in the hotel, attracting a significant amount of students (Lo et al., 2006). Another example of reusing spaces through small modifications so as to attract another market was through turning guest rooms into temporary offices and renting them to corporate clients, after knowing the need of banks and financial services to find different locations for their staff to work in teams and on different teams so as to avoid cross-infection.

The strategy of offering a new product adapted to the new era, according to the way it uses innovation, could be characterised as lateral thinking. In Hong Kong, some restaurants in order to capitalize on people's current emphasis on strengthening their health offered the 'Anti-SARS' menus which claimed to boost consumers' immune system based on Chinese herbal medicine (Tse et al., 2006). On the other hand, some mid-tier hotels offered to their corporate clients at competitive price cleaning services (Lo et al., 2020). In the current era, hotels are adopting artificial intelligence services and robotics, so as to enhance social distancing and protect clients and frontline employees (Jiang \& Wen, 2020). These techniques had already started in some hotels but for other reasons, like the Henn na Hotel in Tokyo which basically offers robotic and virtual staff.

The third strategy of enhancing the social image of a brand was developed in various stages. From one side, businesses in the SARS era, increased their relational marketing by communicating with their clients on a frequent basis after making courtesy calls or sending courtesy emails, based on who the client is, or by informing them over the safety measures they are constantly taking (Tse et al., 2006). From the other side, some brands decided to offer their products or services for free during the lockdown, knowing that this particular lack of economic benefit and this altruistic offering would connect their brand to some 
of the few positive messages that were communicated during the pandemic. Significant examples are from the accommodation sector where various hotels and Airbnb offered without charge their rooms and houses to medical staff that could not go to their home for safety reasons, or from the transportation sector, where taxi associations in Madrid offered a flea of vehicles which transported for free medical staff. On the other hand, from the first day of the lockdown many museums, like the MoMA The Museum of Modern Art in New York, The Louvre Museum in Paris, The Vatican Museum, and the Thyssen-Bornemisza National Museum in Madrid, to name a few, openen online and free of charge their doors and expositions to the public, providing alternatives on cultural experiences inside people's home.

\section{Discussion}

The tourism sector had long ago declared the need to change its management model especially in massively touristified destinations and the pandemic brought upon it the chance to plan these new strategies, whether it was ready or not. Businesses experimented with different targets and learned their qualities, altered their product realizing that space can have more than one utility, and connected their image to a social need, one way or the other. Communicating this originality created more content, new types of discussion through social media, and most importantly the knowledge that a crisis can turn into an opportunity.

Yet, the real challenge lies in applying successful consecutive social marketing campaigns, where consumer behavior adapts into the new suggested patterns of less and more responsible consumption. One of the most basic challenges that communication marketing is facing until the discovery of a vaccine against COVID-19, is the effect of the pass of time in people's perception about the real risk of being affected and in their habits and behavior on a private and public sphere. Responsible tourism as a market segment is gaining new context and people are more forced to comply with its requests than before. The use of appropriate long-term social marketing so as to indicate what must be done and motivate people to do so is necessary for people to feel safe. The practice of lateral thinking from the tourism sector's side is fundamental for businesses to stay economically viable during crisis. Further investigation should focus on analysing the evolution of marketing strategies tourism businesses apply in order to face the long-tail of the pandemic.

\section{References}

- Andearsen A.R. (2002). Marketing Social Marketing in the social change marketplace, Journal of Public Policy and Marketing, 21(1): 3-13

- $\quad$ Apuke O.D. \& Omar B. (2020). Fake news and COVID-19: modelling the predictors of fake news sharing among social media users, Telematics and Informatics, in press

- Brennan, L., \& Binney, W. (2010). Fear, guilt and shame appeals in social marketing. Journal of Business Research, 63(2), 140-146.

- Dutton J. (1993). The making of organizational opportunities: An interpretative pathway to organizational change, Research in Organizational Behavior, 15: 195-226

- Gössling S., Scott D. \& Hall M. (2020). Pandemics, tourism and global change: a rapid assessment of COVID-19, Journal of Sustainable Tourism, in press

- Hastings G., Stead M. \& Webb J. (2004). Fear appeals in Social Marketing: Strategic and ethical reasons for concern, Psychology \& Marketing, 21(11): 961-986

- Hsu Y., Chen Y., Wei H., Yang Y. \& Chen Y. (2017). Risk and Outbreak Communication: Lessons from 
Taiwan's Experiences in the Post-SARS Era, Health Security, 15(2): 165-169

- Japerson A.E. \& Fan D.P. (2002). An aggregate examination of the blacklash effect in political advertising: The case of the 1996 U.S. Senate race in Minnesota, Journal of Advertising, 31: 1-12

- Jiang Y. \& Wen J. (2020). Effects of COVID-19 on hotel marketing and management: a perspective article, International Journal of Contemporary Hospitality Management, 32(8), in press

- Koh E. (2020). The end of over-tourism? Opportunities in a post-Covid-19 world, International Tourist Studies, in press

- Kotlet P. \& Trías de Bes (2003). Lateral Marketing: New techniques for finding breakthrough ideas, John Wiley \& Sons, Inc., Hoboken, New Jersey

- La Vanguardia (2020). Los mercados municipales multiplican por diez las ventas en red con la pandemia, (18/05/2020), available in https://www.lavanguardia.com/local/barcelona/20200518/481250186352/mercados-municipales-multiplican-diez-ventas-red-coronavirus-barcelona.html

- La Vanguardia (2020). Menos del 10\% de restaurantes sigue activo gracias al 'delivery', (14/04/2020), available in https://www.lavanguardia.com/local/barcelona/20200414/48485028527/restaurantes-impacto-coronavirus-delivery-actividad.html

- $\quad$ Lo A., Cheung C. \& Law R. (2006). The survival of hotels during disaster: A case study of Hong Kong in 2003, Asia Pacific Journal of Tourism Research, 11(1): 65-80

- MacAskill S., Will V., Hughes K. \& Eadie D. (1993). The Health Education Board of Scotland's 1992 anti-smoking initiative. Glasgow, Scotland: University of Strathclyde, Centre for Social Marketing

- Malynka O. \& Perevozova I. (2019). Comparison of lateral vs. vertical marketing concepts in brand creation process, Technology Audit and Production Reserves, 46(2/4): 43-45

- Mao C., Ding C. \& Lee H. (2010). Post-SARS tourist arrival recovery patterns: an analysis based on a catastrophe theory, Tourism Management, 31(6): 855-861

- $\quad$ Mao C., Ding C.G. \& Lee H. (2010). Post-SARS tourist arrival recovery patterns: An analysis based on a catastrophe theory, Tourism Management, 31: 855-861

- Menon K.U. (2006). SARS Revisited: Managing "outbreaks" with "communications", Annals of the Academy of Medicine, Singapore 35(5):361-7

- Olsson L.E., Huck J. \& Froman M. (2018). Intention for Car Use Reduction: Applying a Stage-Based Model, International Journal of Environmental Research and Public Health, 15(2): 216. doi: 10.3390/ ijerph15020216

- Pearson M. \& Mitroff I.I. (1993). From crisis prone to crisis prepared: a framework for crisis management, Academy of Management Perspectives 7(1): 48-59

- Peattie K. \& Peattie S. (2009). Social marketing: A pathway to consumption reduction?, Journal of Business Research, 62(2): 260-268

- Quintal V.A., Lee, J.A. \& Soutar, G.N. (2010). Risk, uncertainty and the theory of planned behavior: A tourism example, Tourism Management, 31(6): 797-805

- $\quad$ Rothschild M.L. (1999). Carrots, sticks, and promises: A conceptual framework for the management of public health and social issue behaviors, Journal of Marketing, 63: 24-37

- $\quad$ Seraphin, H. \& Dosquet, F. (2020), "Mountain tourism and second home tourism as post COVID-19 lockdown placebo?", Worldwide Hospitality and Tourism Themes, 12(4): 485-500

- $\quad$ Staw, B.M, Sandelands, L.E., \& Dutton, J.E. (1981). Threat Rigidity Effects in Organizational Behavior: A Multilevel Analysis, Administrative Science Quarterly 26(4): 501-524

- Tse A.C.B., So S. \& Sin L. (2006). Crisis management and recovery: how restaurants in Hong Kong responded to SARS, Hospitality Management, 25: 3-11 
- UNWTO (2020). UNWTO highlights potential of domestic tourism to help drive economic recovery in destinations worldwide, available in https://www.unwto.org/news/unwto-highlights-potential-of-domestic-tourism-to-help-drive-economic-recovery-in-destinations-worldwide

\section{CURRICULUM VITAE}

Dr. Konstantina Zerva is a Professor of Marketing and Market Investigation at the University of Girona. She has a PhD in Humanities from the Autonomous University of Barcelona on the subject of social exchanges related to the consumption of culture. Her main lines of research are related to consumer behavior towards products or contexts of social conflicts, the analysis of niche tourism market segments, social marketing and theories of social exchange, through the use of qualitative methods of data analysis. She has published in indexed journals, such as Tourism Management, Tourism Geographies, and Acta Sociologica. 